\author{
Anna Gdakowicz* \\ Uniwersytet Szczeciński \\ Józef Hozer** \\ Uniwersytet Szczeciński \\ Wojciech Kuźmiński*** \\ Uniwersytet Szczeciński
}

\title{
LINIE OPORU I WSPARCIA NA RYNKACH NIERUCHOMOŚCI MIESZKANIOWYCH I ROLNYCH
}

\section{Streszczenie}

Rynek mieszkań i rynek gruntów rolnych tylko z pozoru zaliczyć można do tej samej grupy - rynków nieruchomości. W tym samym czasie mogą zachodzić na nich zupełnie inne procesy. Wzrostom cen gruntów rolnych towarzyszyć może spadek cen mieszkań i odwrotnie. Rynki te należy analizować oddzielnie, ale trzeba mieć świadomość ich wzajemnego przenikania. Zachodzące procesy na jednym rynku mogą mieć na drugim swoje konsekwencje obecnie, ale również w przyszłości. Należy więc poszukiwać charakterystycznych punktów zwrotnych dynamiki zjawisk na rynkach nieruchomości. W pracy podjęto próbę wykorzystania narzędzi finansowej analizy technicznej do analizy rynków nieruchomości, ze szczególnym uwzględnieniem linii oporu i linii wsparcia.

Słowa kluczowe: linia oporu, linia wsparcia, rynek nieruchomości mieszkaniowych, rynek nieruchomości rolnych

* Adres e-mail: alatko@wneiz.pl.

** Adres e-mail: hozer@wneiz.pl.

*** Adres e-mail: pyrzyce@wneiz.pl. 


\section{Wprowadzenie}

Ekonomiczne szeregi czasowe tworzą jedną z czterech prawidłowości statystycznych, dotyczącą dynamiki' Ekonomiści, szukając tych prawidłowości, doskonalą narzędzia opisu i prognozowania (Zieliński 1979; Hozer, Zawadzki 1990; Beksiak, Ciżkowicz, Karnowski 2013; Hozer 2014; Hendry, Ericsson 2003). Bywa, że narzędzie ekonometrycznego opisu dobrze opisuje zaszłość, ale nie daje możliwości prognozowania zjawisk, ponieważ ekonomiczne szeregi czasowe ulegają nagłym zmianom trudnym do przewidzenia: raz na skutek interwencji ludzkiej, innym razem na skutek efektu czasowego ${ }^{2}$. Jeszcze innym razem zmiana tendencji rozwojowej może być przypadkowa. Powstaje więc potrzeba poszukiwania mechanizmów, które dynamizują lub hamują zachowanie się systemów ekonomicznych. Co dynamizuje rozwój rynku nieruchomości mieszkaniowych? Takim czynnikiem jest przewaga popytu nad podażą, popyt ze strony bogatych nabywców. Czynniki te wpływają na wzrost cen mieszkań. Co ogranicza wzrost cen mieszkań? Takim czynnikiem jest dochód potencjalnego nabywcy wpływający na poziom ceny akceptowanej przez rynek (przez potencjalnych nabywców). W miarę nasycania rynku ofertą podażową wzrost cen wyhamowuje. W efekcie konkurencji ceny zaczynają spadać. Jaka jest dolna granica cen mieszkań na danym segmencie rynku? W znacznym stopniu zależy to od rozmiaru konkurencji oraz od kosztów wytworzenia substancji mieszkaniowej. Ceny w czasie falują, raz rosną, innym razem spadają. Istnieją naturalne trudności w przewidywaniu tych spadków i wzrostów. $Z$ pomocą może przyjść budowa teorii działania mechanizmów dynamizujących i mechanizmów wyhamowujących wzrost (spadek) cen. Warto zidentyfikować fakty, zdarzenia, które tworzą ograniczenia górne i dolne w falowaniu cen na rynkach nieruchomości. Na rynku nieruchomości mieszkaniowych barierę dolną dla cen $1 \mathrm{~m}^{2}$ wyznacza koszt wykonania. Budujący mieszkania nie może ich zbywać po cenie niższej od kosztów wytworzenia.

Na rynku nieruchomości rolnych obserwujemy wzrost cen od wielu lat. Wzrost spowodowany jest przewagą popytu (często spekulacyjnego) nad ofertą podażową. Jaka jest górna granica wzrostu cen nieruchomości rolnych? Wydaje się, że przy obecnych uwarunkowaniach granice wyznaczać będzie cena nieruchomości rolnych w krajach zachodnich. Wpływ na ceny wywiera również renta gruntowa. Rynek nie-

1 Oprócz prawidłowości związków w czasie i przestrzeni oraz rozkładów.

2 Efektem czasowym może być np. zestarzenie się struktury lub wręcz jej anihilacja. 
ruchomości mieszkaniowych i rolnych podlega też wpływom politycznych działań (nie tylko w Polsce, ale i w Europie). Falowanie, wzrosty, spadki szeregów czasowych cen, podaży, wydatków ze strony nabywców wymagają analiz i diagnoz jako podstawy podejmowania decyzji przez sprzedających, kupujących i rządzących. W warunkach gospodarki wolnorynkowej istnieje potrzeba działań w zakresie sterowania rynkiem.

Józef Hozer (2000, s. 89-91) przedstawił pogląd o ograniczeniu wolnego rynku w zakresie obrotu ziemią i zastosowanie rozwiązania francuskiego SAFER. Oznacza to znaczną ingerencję rządzących w zakresie kształtowania falowania, wzrostów i spadków szeregów czasowych na rynku nieruchomości rolnych: cen, podaży, wydatków kupujących itd. Jest to postulat aplikacji trzeciej drogi rozwoju, czyli kapitalizmu społecznego, a więc interwencjonizmu opartego na naukowych analizach, diagnozach i prognozach (ostrzegawczych lub przewidujących).

Przedstawione poniżej badania odnoszą się do dwóch pojęć: górnej granicy wzrostu i dolnej granicy spadku na rynkach nieruchomości mieszkaniowych i rolnych. Wydaje się, że eksploracja tych pojęć może być przydatna w zakresie opisu szeregów i kreowania właściwej polityki na tych rynkach. Modelowanie ekonometryczne linii wsparcia i oporu może być użytecznym narzędziem diagnoz oraz prognoz zachowań poszczególnych rynków. Przy czym oba rynki wyraźnie się między sobą różnią, jeżeli chodzi o dynamikę wybranych zjawisk, i wymagają oddzielnych analiz.

W artykule przedstawiono sposoby wyznaczania linii oporu i wsparcia wykorzystywane w analizie technicznej, a następnie zaadaptowano je na potrzeby rynku nieruchomości. Dla rynku nieruchomości mieszkalnych poszukiwano linii wsparcia, natomiast dla rynku nieruchomości rolnych - linii oporu.

\section{Linie oporu i wsparcia na rynkach kapitałowych}

W analizie technicznej ważnymi pojęciami są opór i wsparcie. Kursy spółek notowanych na giełdzie podlegają częstym zmianom kierunku. Kurs rośnie, następnie spada, po czym znowu rośnie, wahając się w zakresie wyznaczonym przez poprzednie wierzchołki lub dna notowań. Gdy cena rośnie, osiągając coraz wyższe poziomy, ale nie może przebić się przez określony poziom, mówi się o oporze. Opór jest zatem takim poziomem ceny, na którym sprzedający stają się bardziej aktywni 
od kupujących, przez co cena zaczyna spadać. Linia poprowadzona przez wierzchołki wzrostów cen nazywana jest linią oporu.

Wsparcie dotyczy poziomu cen, poniżej którego kurs nie spada. Jest to moment, kiedy popyt przewyższa podaż, co wpływa na zahamowanie spadku cen i powoduje ich wzrost. Linia wyznaczona przez dołki cen nazywana jest linią wsparcia. Poziomy wsparcia i oporu mogą być wyznaczone na podstawie m.in. linii i kanałów trendu, średnich ruchomych lub poziomów Fibonacciego. Linie trendu wyznaczane są na podstawie lokalnych ekstremów cenowych. Lokalne maksima tworzą linię oporu, natomiast minima - linię wsparcia (rysunek 1). Przestrzeń między liniami trendu nazywana jest kanałem trendu.

Rysunek 1. Linia wsparcia i oporu wyznaczona na podstawie linii trendu

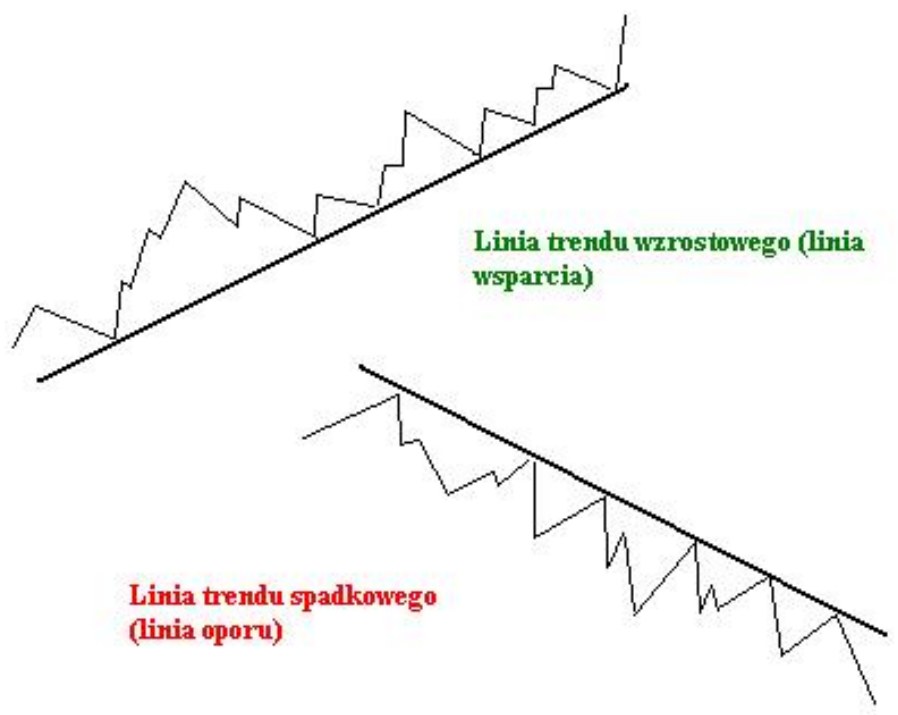

Źródło: opracowanie własne.

Średnie ruchome obliczane są na podstawie notowań z określonej liczby sesji. W analizie technicznej najczęściej wykorzystuje się średnie krótkoterminowe: 15 lub 45 okresowe. Wskaźniki te są powszechnie stosowane ze względu na łatwość obliczeń i interpretacji. Średnie krótkoterminowe są bardziej wrażliwe na zmianę 
kursu niż średnie długoterminowe. Jako linie oporu lub wsparcia wykorzystywane są średnie długoterminowe - 100 lub 200 okresowe.

Wykorzystanie liczb Fibonacciego w analizie technicznej wiąże się z określeniem zniesień wynikających z podzielenia dwóch sąsiednich liczb w ciągu Fibonacciego $(61,8 \%)$ oraz z podzielenia liczb odległych o dwa miejsca w ciągu $(38,2 \%)$. Wskaźniki te odzwierciedlają procentowy udział długości kolejnej fali w fali bazowej. W przypadku gdy cena akcji zaczyna rosnąć, to za pomocą poziomów wyznaczonych na podstawie ciągu liczb Fibonacciego można z pewnym prawdopodobieństwem wskazać długość zniesienia korekcyjnego. Najczęściej korekty zatrzymują się na poziomie 38,2\% lub 61,8\% długości poprzedzającego je impulsu (Nowakowski, Borowski 2006). Zniesienia Fibonacciego stanowią jednocześnie wsparcie lub opór kursu akcji.

Kiedy poziom wsparcia zostanie przełamany, zaczyna odgrywać rolę oporu. Również kiedy opór zostanie przełamany - zaczyna być traktowany jako wsparcie.

\section{Segmentacja czasowa i przestrzenna rynków nieruchomości}

Nie ma jednolitego rynku nieruchomości (Kucharska-Stasiak 1997, s. 31). Rozpatrując rynek nieruchomości ze względu na kryterium przedmiotowe, wyróżnić należy m.in. rynek nieruchomości mieszkaniowych oraz rynek nieruchomości rolnych. Rynek nieruchomości mieszkaniowych obejmuje lokale mieszkalne, domy jednorodzinne i wielorodzinne. Rynek nieruchomości rolnych to grunty rolne, pastwiska, łąki, sady, plantacje kultur wieloletnich. Oba wymienione rynki nieruchomości charakteryzują się własną specyfiką i dynamiką rozwoju. Na rozwój tych rynków nieruchomości mają wpływ różne czynniki społeczno-gospodarcze. Oba rynki są też odmiennie uwarunkowane prawnie. Ze względu na odmienną charakterystykę każdy z tych rynków powinien być analizowany osobno.

Rynek nieruchomości mieszkaniowych (domów i mieszkań) ma charakter lokalny, co oznacza, że poszukujący nieruchomości na tym rynku ograniczają się do oferty w najbliższej okolicy. Kupujący nie są skłonni do zakupu domu w innej miejscowości, mimo niższych cen. Popyt na nieruchomości mieszkaniowe jest zaspokajany w sąsiedztwie. Lokalny charakter rynku nieruchomości mieszkaniowych powoduje, że rynki te odznaczają się własną dynamiką rozwoju. 
Porównując ceny domów w Wielkiej Brytanii (rysunek 2), zauważyć należy, że do 2004 r. ceny rosły we wszystkich trzech wybranych regionach. W kolejnych kwartałach ceny kształtowały się odmiennie. W Londynie ceny domów nadal rosły do przełomu 2007 i 2008 r., w kolejnym roku obserwowano ich spadek, a od I kwartału 2009 r. do końca 2014 r. - ponowny wzrost (chociaż w różnych okresach i z różną dynamiką). W północnej Irlandii natomiast ceny domów rosły w zbliżonym tempie do 2006 r., a od I kwartału 2006 do III kwartału 2007 r. ceny wzrosły bardzo dynamicznie (o 25\%). Od końca 2007 r. ceny domów spadały. Jeszcze inną zmiennością cen charakteryzował się region północno-zachodni Wielkiej Brytanii. Ceny domów rosły do 2007 r., a następnie ustabilizowały się na poziomie około 150 tys. £.

Rysunek 2. Dynamika cen domów w wybranych regionach Wielkiej Brytanii w kwartałach lat 1992-2014 [£]

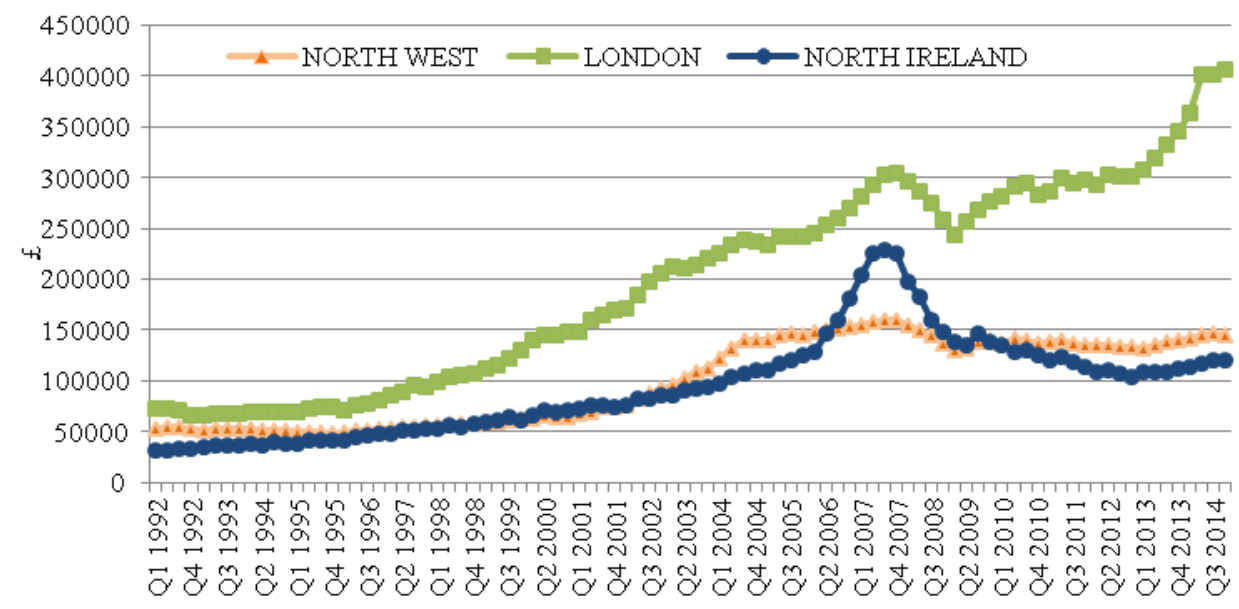

Źródło: opracowanie własne na podstawie www.nationwide.co.uk/about/houseprice-index/headlines (15.03.2015). 


\section{Linia wsparcia na rynku mieszkań w Szczecinie}

Cena nieruchomości mieszkaniowych jest wypadkową wielu czynników. Na jej wysokość mają wpływ czynniki demograficzne, ekonomiczne, prawne i inne. Wśród czynników demograficznych wymienić należy liczbę i strukturę ludności (inne potrzeby mieszkaniowe generuje osoba samotna, a inne rodzina wielodzietna), liczbę zawieranych małżeństw (młodzi ludzie będą zgłaszali zapotrzebowanie na własny lokal mieszkalny) oraz liczbę rozwodów (tworzą się dwa oddzielne gospodarstwa domowe). Wzrost wszystkich wymienionych czynników demograficznych wpływa na wzrost popytu na nieruchomości mieszkaniowe, a przez to na wzrost ich cen.

Do czynników ekonomicznych istotnie wpływających na ceny nieruchomości mieszkalnych zaliczyć należy: poziom bezrobocia (który negatywnie wpływa na nieruchomości mieszkaniowe), wysokość dochodów (wpływ pozytywny), organizację sektora bankowego i dostępność kredytową (im więcej osób ma zdolność kredytową, tym większy generują popyt). Dostępność kredytowa wynika w dużej mierze z poziomu stóp procentowych oraz innych bodźców fiskalnych. Cena nieruchomości mieszkalnych zależy również od jej relacji do przeciętnych zarobków oraz do przeciętnych stawek za wynajmowane powierzchnie mieszkaniowe.

Wpływ uregulowań prawnych na rynek nieruchomości mieszkaniowych zauważalny jest na każdym etapie inwestycji w nieruchomości. Od ochrony praw lokatorów, aż po programy rządowe wspomagające zakup nieruchomości. Równie istotne jak aktualny stan prawny są informacje na temat przyszłych uregulowań prawnych, np. zapowiedź zniesienia ulgi budowlanej spowodowała wzrost zainteresowania nieruchomościami mieszkalnymi jeszcze w trakcie jej obowiązywania.

Do czynników wpływających na rynek nieruchomości mieszkaniowych zaliczyć należy oczekiwania co do przyszłych cen nieruchomości, przystąpienie Polski do Unii Europejskiej, kryzys gospodarczy i inne.

Przeciętna cena $1 \mathrm{~m}^{2}$ nieruchomości mieszkaniowej w Szczecinie w $2014 \mathrm{r}$. w porównaniu do $1992 \mathrm{r}$. wzrosła ponad 1000-krotnie na rynku pierwotnym i ponad 800-krotnie na rynku wtórnym (rysunek 3). Stały wzrost cen nieruchomości obserwowany był do 2006 r. i wynikał on przede wszystkim z: poprawy sytuacji finansowej mieszkańców, poprawy organizacji rynku nieruchomości w Polsce, pobudzania tego rynku przez ulgi i programy rządowe, a także przystąpienia Polski do Unii Europejskiej. Najdynamiczniej ceny wzrastały w latach 2006-2008. Był to wzrost 
spekulacyjny, który finansowany był z łatwo dostępnych kredytów hipotecznych i w konsekwencji doprowadził do korekty cen nieruchomości mieszkaniowych na kolejne lata. Dodatkowo ogólnoświatowy kryzys gospodarczy wpłynął również na Polską gospodarkę: zwiększyło się bezrobocie, a banki usztywniły swoje stanowisko w sprawie udzielania kredytów - na rynku brak było wolnych środków finansowych na zakup nieruchomości.

Rysunek 3. Dynamika przeciętnej ceny $1 \mathrm{~m}^{2}$ nieruchomości mieszkaniowej w Szczecinie w kwartałach lat 1992-2014

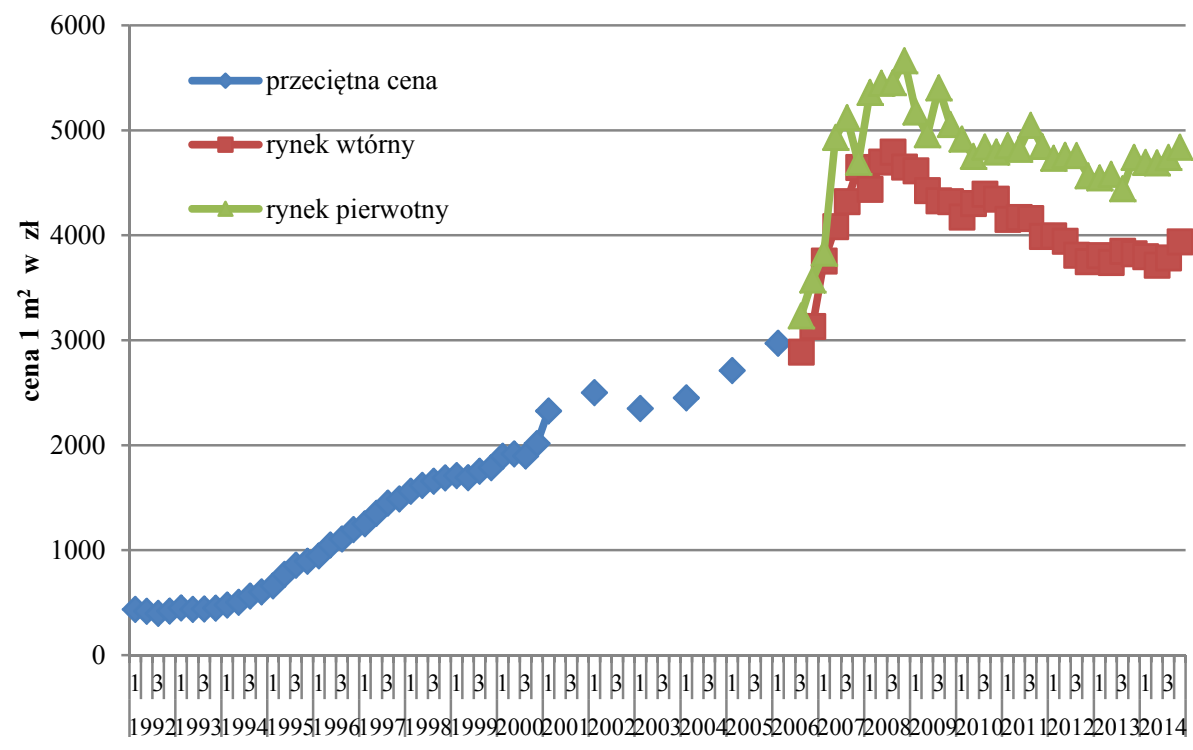

Źródło: opracowanie własne.

Do 2008 r., gdy przeciętne ceny rosły, można mówić o występowaniu linii oporu przeciętnej ceny $1 \mathrm{~m}^{2}$ nieruchomości mieszkaniowej. Od 2009 r. natomiast (spadek cen) o linii wsparcia.

Sposób wyznaczania linii wsparcia dla cen nieruchomości mieszkaniowych różni się od sposobów wykorzystywanych na rynku kapitałowym. Ponieważ ceny nieruchomości mieszkaniowych nie mogą być niższe niż koszt wytworzenia (szcze- 
gólnie nieruchomości dostępnych na rynku pierwotnym), linię wsparcia wyznaczono na podstawie wskaźnika przeliczeniowego kosztów odtworzenia metra kwadratowego powierzchni użytkowej budynków mieszkalnych (rysunek 4). Wskaźnik ten jest co pół roku ustalany przez wojewodę i obliczany oddzielnie dla województwa i miasta wojewódzkiego. Podstawą jego wyliczenia jest średni w województwie (mieście) koszt budowy $1 \mathrm{~m}^{2}$ powierzchni użytkowej budynku mieszkalnego, określany przez wojewódzki oddział GUS. Przy szacowaniu wskaźnika uwzględniany jest również wzrost cen towarów i usług konsumpcyjnych w danym województwie w ostatnich sześciu miesiącach.

Rysunek 4. Relacja ceny i kosztów wytworzenia $1 \mathrm{~m}^{2}$ mieszkania

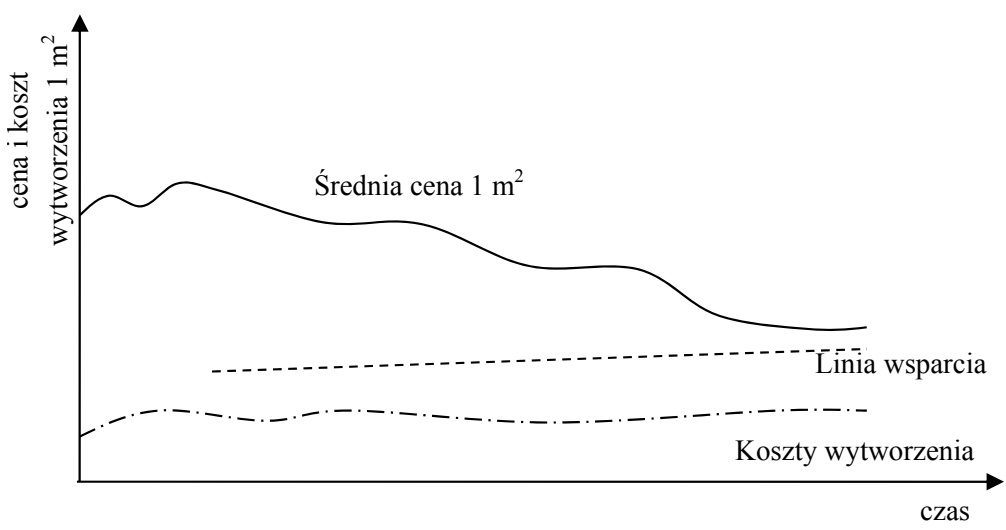

Źródło: opracowanie własne.

Linia wsparcia może się zmieniać: maleć, gdy wykonawcy obniżają koszty wykonania, lub rosnąć, gdy wykonawcy chcą podążać za wymaganiami kupujących co do standardu wykonania. Linia wsparcia kształtuje się powyżej rzeczywistych kosztów budowy.

Luka między linią wsparcia a przeciętną ceną $1 \mathrm{~m}^{2}$ nieruchomości stanowi zysk dewelopera. W okresie koniunktury na rynku nieruchomości luka powiększa się (inwestor zyskuje więcej), w czasach dekoniunktury natomiast, gdy deweloperzy zmuszeni są do korekty cen nowych nieruchomości, luka ulega zmniejszeniu. 
W latach 2008-2014 przeciętne ceny nieruchomości mieszkaniowych w Szczecinie malały. Wskaźnik przeliczeniowy kosztu odtworzenia $1 \mathrm{~m}^{2}$ wykazywał natomiast stałą tendencję rosnącą. Luka między przeciętną ceną $1 \mathrm{~m}^{2}$ nieruchomości mieszkaniowej na rynku pierwotnym a kosztem wytworzenia zmniejszała się. Cena $1 \mathrm{~m}^{2}$ nie przebiła jednak linii wsparcia ${ }^{3}$.

Wyznaczono linię trendu dla analizowanej linii wsparcia. Oszacowana funkcja trendu liniowego charakteryzowała się bardzo dobrym dopasowaniem oraz istotnością parametrów:

$$
\begin{aligned}
y_{t}= & 3188,77+31,96 t+e_{t}, \\
(28,25) \quad(1,59) \quad(75,44) & R^{2}=93,5 \%,
\end{aligned}
$$

gdzie: $y_{t}$ - wskaźnik przeliczeniowy kosztu odtworzenia (linia wsparcia), $t-$ zmienna czasowa.

Rysunek 5. Ceny transakcyjne na rynku pierwotnym, linia wsparcia $1 \mathrm{~m}^{2}$ mieszkania oraz wartości teoretyczne linii wsparcia z prognozą na kolejne lata w Szczecinie w okresie I kw. 2007 - IV kw. 2016 [zł/m²]

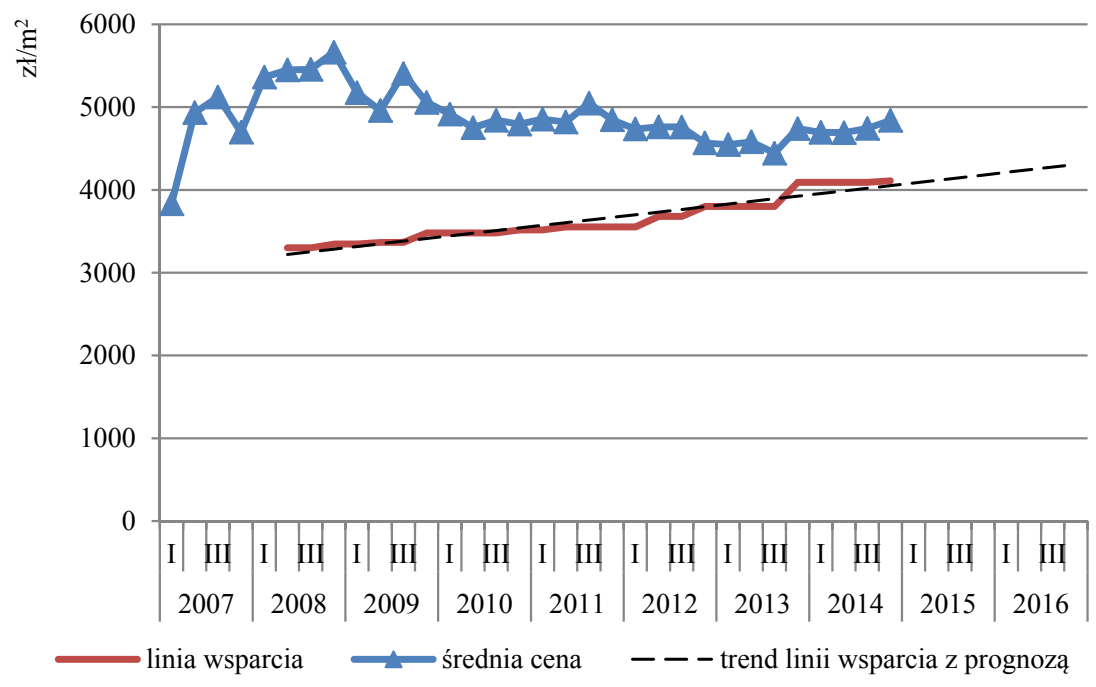

Źródło: opracowanie własne.

3 Taka sytuacja była obserwowana w innych miastach Polski (Gdakowicz 2014). 
Prognoza linii wsparcia na kolejne lata wskazuje minimalny poziom ceny $1 \mathrm{~m}^{2}$ lokalu mieszkalnego na rynku pierwotnym w Szczecinie. W najbliższych latach cena ta nie powinna być niższa (jeśli sprzedaż nowych mieszkań ma być rentowna) niż 4180 zł w 2015 r. i 4300 zł na koniec 2016 r.

\section{Linia oporu na rynku nieruchomości rolnych w Polsce}

W Polsce od wielu lat ceny nieruchomości rolnych systematycznie rosną. Dotyczy to zarówno pierwotnego, jak i wtórnego rynku, przy czym za rynek pierwotny przyjmuje się te nieruchomości, które zbywane są z Zasobu Własności Rolnej Skarbu Państwa (ZWRSP). Zasób ten jest prowadzony przez Agencję Nieruchomości Rolnych (ANR), którą powołano do życia na mocy ustawy z 1991 r. o gospodarowaniu nieruchomościami rolnymi Skarbu Państwa i która do 2003 r. zwana była Agencją Własności Rolnej Skarbu Państwa (AWRSP). ANR jest kontynuatorem prawnym AWRSP. Agencja przejęła od ZWRSP ponad 4,8 mln ha gruntów rolnych (głównie po zlikwidowanych 1666 PGR-ach, ale również z Państwowego Funduszu Ziemi i w niewielkiej części z innych źródeł), stając się monopolistą na rynku nieruchomości rolnych. Sprzedaż nieruchomości z ZWRSP odbywa się za pośrednictwem przetargów ustnych lub ofertowych, nieograniczonych i ograniczonych do wybranych grup społecznych. W przypadku dzierżawy przez okres co najmniej 3 lat oraz przy spełnieniu innych warunków sprzedaż może nastąpić w ramach pierwszeństwa nabycia (po cenie oszacowania przez rzeczoznawcę majątkowego). Dynamikę średnich cen nieruchomości zbywanych przez ANR przedstawiono na rysunku 6 .

Analiza danych przedstawionych na rysunku 6 potwierdza tezę o wzrostowej tendencji cen nieruchomości rolnych SP w całym okresie funkcjonowania ANR w otoczeniu rolnictwa, przy czym zauważyć można kilka faz tych wzrostów. Pierwsza zasadnicza faza przypada na okres przejmowania nieruchomości do ZWRSP i wiąże się z nadpodażą gruntów rolnych, stąd też stosunkowo łagodny wzrost. Drugi okres (1999-2003) to czas wolniejszych wzrostów w oczekiwaniu na decyzje dotyczące wejścia Polski od UE. Od 2004 r. obserwowany jest już bardzo dynamiczny wzrost cen nieruchomości rolnych. Sprzyjała temu zjawisku nie tylko preferencyjna sprzedaż nieruchomości z Zasobu (możliwość rozłożenia sprzedaży na raty oraz niższe niż rynkowe oprocentowanie kredytów), ale również wielokierunkowa pomoc unijna dla rolników. Po 2010 r. widać oznaki kolejnej fazy wzrostów związanych 
z planowanym na 2016 r. uwolnieniem sprzedaży na rzecz cudzoziemców (rysunek 7). Tylko od przygotowywanych instrumentów prawnych państwa (ochronnych przed spekulacją) zależeć będzie, czy dynamika ta będzie jeszcze większa niż dotychczas.

Rysunek 6. Dynamika cen nieruchomości rolnych zbywanych z ZWRSP w latach 1992-2014 [zt/ha]

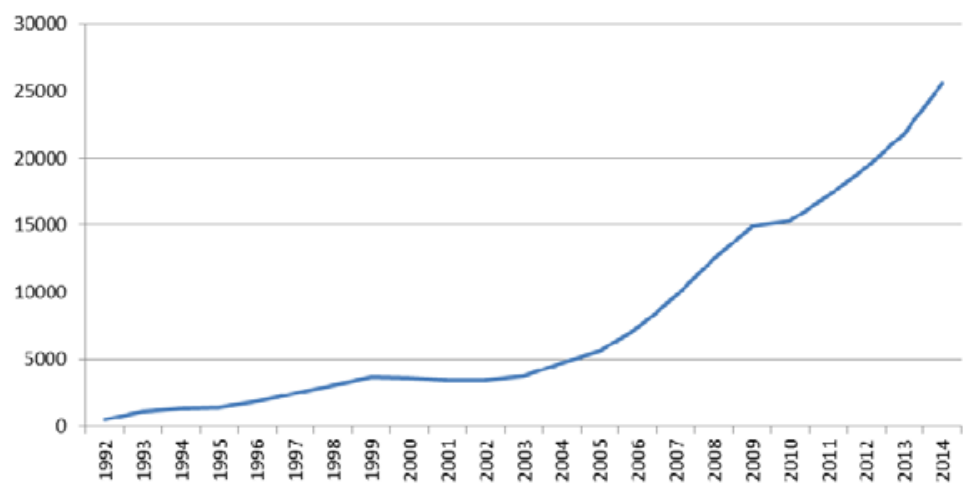

Źródło: opracowanie własne na podstawie danych Agencji Nieruchomości Rolnych.

Rysunek 7. Fazy wzrostu cen nieruchomości rolnych zbywanych z ZWRSP w latach 1992-2014

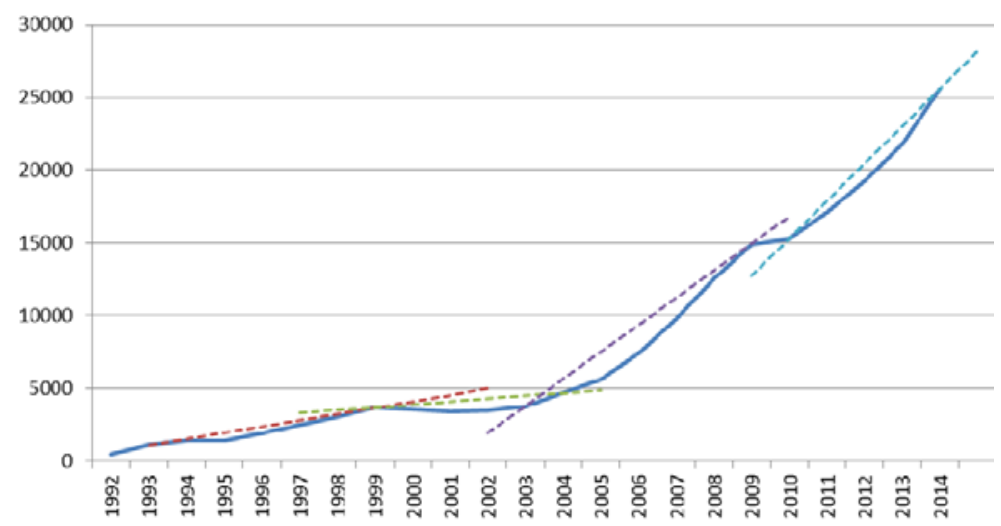

Źródło: opracowanie własne na podstawie danych Agencji Nieruchomości Rolnych. 
Tabela 1. Zmiany wartości współczynników kierunkowych linii oporu w poszczególnych fazach wzrostu

\begin{tabular}{|c|c|}
\hline Faza & Oszacowania współczynników kierunkowych \\
\hline Faza 1 & 430,7 \\
\hline Faza 2 & 320,5 \\
\hline Faza 3 & 1861,5 \\
\hline Faza 4 & 2454,8 \\
\hline
\end{tabular}

Źródło: obliczenia własne na podstawie danych Agencji Nieruchomości Rolnych.

Przy tak obserwowanej dynamice cen nieruchomości rolnych można zadać pytanie o maksymalny spodziewany ich wzrost. Wydaje się, że w najbliższej przyszłości linia oporu będzie przebiegać zgodnie z tendencją wyznaczoną dla ostatniej, 4 fazy (tabela 1), tj.:

$$
\widehat{y}_{t}=2454,8 t-31359,25
$$

W przyszłości nie można wykluczyć korekty cen, tak jak to miało miejsce na rynku nieruchomości mieszkaniowych. Istnienie bańki spekulacyjnej na rynku nieruchomości rolnych pokazuje przykład irlandzki. W kraju tym rynek gruntów rolnych był modelowym przykładem tworzenia bańki popytu wywołanego dużymi zakupami gruntów na cele zabudowy nierolniczej. W 2008 r., po wejściu gospodarki kraju w stan recesji, załamanie na rynku nieruchomości doprowadziło również do gwałtownego spadku cen gruntów rolnych. Od 2010 r. ceny irlandzkiej ziemi rolnej ponownie wykazują lekką tendencję wzrostową. W przypadku polskiego rynku nieruchomości rolnych taka sytuacja nie nastąpiła mimo licznych podobieństw (recesja gospodarcza oraz obserwowany duży procent wyłączeń gruntów rolnych z produkcji). Spowodowane to było kilkoma czynnikami ${ }^{4}$.

Pierwszy to stale zwiększająca się wydajność polskiego rolnictwa przekładająca się pozytywnie na stronę popytową na rynku nieruchomości rolnych (rysunek 8). Przykładowo plony zbóż w poszczególnych latach ulegały wahaniom wynikającym ze zmienności warunków pogodowych (Rynek zbóż... 2013). W dłuższym horyzon-

\footnotetext{
4 Inne czynniki szczegółowo opisano w pracy: Hozer, Kuźmiński (2013).
} 
cie czasowym rysuje się jednak wyraźna tendencja wzrostowa. Do wzrostu zbiorów przyczynia się zmiana struktury uprawy zbóż, postęp biologiczny w zakresie hodowli nowych odmian oraz poprawa efektywności stosowania środków plonotwórczych i ochrony roślin.

Rysunek 8. Przeciętne plony zbóż w Polsce z 1 ha w ujęciu wegetacyjnym w okresie 2000/2001 - 2013/2014 [dt/ha]

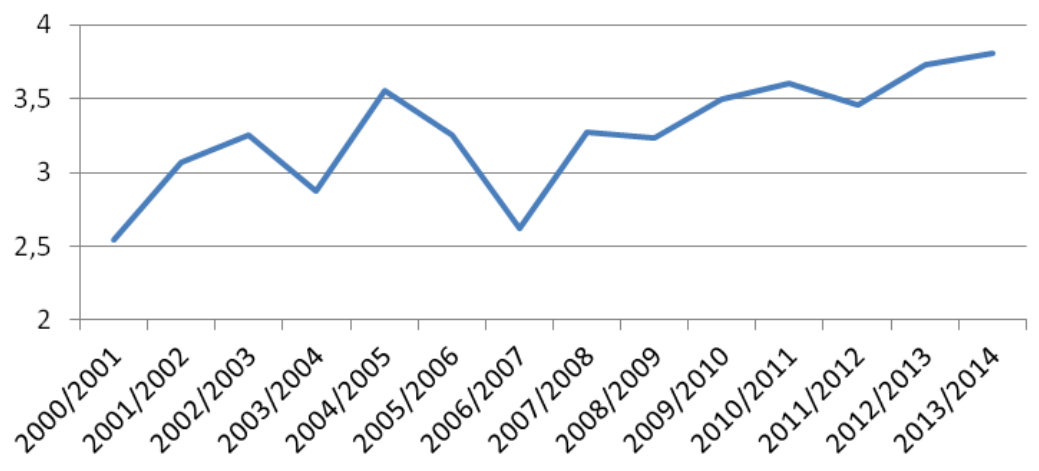

Źródło: opracowanie własne na podstawie Rynek zbóż... (2013).

Ze względu na istniejące nadal dysproporcje wydajności upraw w Polsce i w rozwiniętych krajach UE oraz obserwowaną konwergencję w tym zakresie należy oczekiwać, że w najbliższych latach wydajność w rolnictwie nie będzie czynnikiem wyhamowującym ceny ziemi rolniczej, a raczej je dynamizującym.

Jak wspomniano we wstępie, wzrost cen nieruchomości rolnych spowodowany jest również przewagą popytu (często spekulacyjnego) nad ofertą podażową. Popyt spekulacyjny kreowany jest ze względu na istniejące ograniczenia w handlu ziemią i nieszczelne ustawodawstwo, prowadzące do zakupów „na słupa”. Wiele krajów bogatszych od Polski wprowadziło mechanizmy ochronne dla takiej spekulacji. Najbardziej znane z nich to francuskie Les sociétés d'aménagement foncier et d'établissement rural - SAFER. Podstawę gospodarki rolnej we Francji stanowią gospodarstwa o średniej powierzchni 60 ha, przy czym częste są 300-hektarowe gospodarstwa produkujące zboża. 
We Francji w przypadku każdej transakcji powyżej 1 ha notariusz musi powiadomić państwowe SAFER, a odpowiedzialni urzędnicy mają dwa miesiące na podjęcie decyzji o skorzystaniu z prawa pierwokupu. SAFER również samo wycenia nieruchomość, którą zamierza nabyć. Robi to na podstawie własnych baz danych, które gromadzi na temat transakcji sprzedaży gruntów w okolicy. Właściciel ma możliwość sądowej jej weryfikacji. W sytuacji kiedy sąd uzna, że wycena dokonana przez SAFER jest uzasadniona, wtedy rolnik może albo wycofać grunty rolne ze sprzedaży, albo sprzedać je SAFER za cenę przez nie zaproponowaną.

Działalność SAFER może wydawać się nawet dość drastyczna z perspektywy farmerów, bo nie mogą oni sami zdecydować, komu i za ile sprzedadzą ziemię. W praktyce rozstrzygają to urzędnicy, często preferując lokalnych farmerów po szkole rolniczej, osoby młode, niedysponujące wielkimi areałami. Po sprzedaży ziemi takim wybranym osobom ich gospodarstwo nadal pozostaje nieduże. Oprócz pilnowania struktury obszarowej gospodarstw SAFER ma też za zadanie kontrolować ceny gruntów i wyeliminować z rynku spekulantów. Za hektar ziemi rolnej we Francji trzeba było w 2012 r. zapłacić średnio 5400 euro, to dużo mniej niż w innych krajach UE (rysunek 9).

Rysunek 9. Przeciętne ceny ziemi rolnej we Francji i wybranych krajach UE w 2012 r. [€/ha]

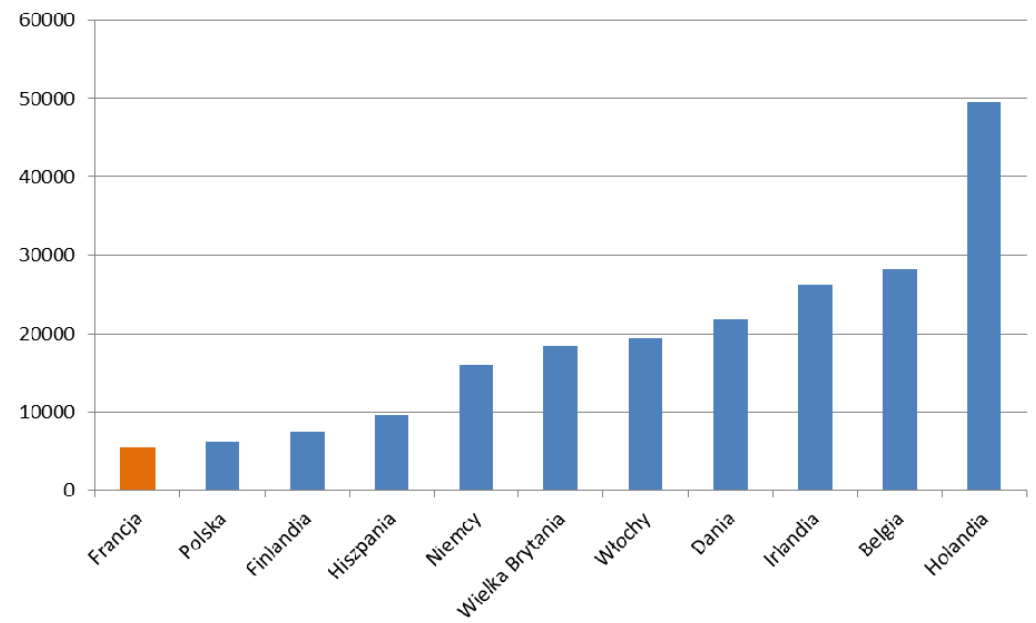

Źródło: opracowanie własne na podstawie danych Eurostat. 
Polityka państwa polskiego i ustawodawstwo, jakie w tym zakresie będzie wprowadzone, rozstrzygną, czy popyt spekulacyjny będzie nadal czynnikiem dynamizującym ceny gruntów rolnych, czy podobnie jak we Francji stanie się czynnikiem spowalniającym.

Warto również zaznaczyć, jak duży wpływ na strukturę agrarną ma działalność SAFER. Francja ma jeden z niższych współczynników koncentracji gruntów rolnych - 0,51 (wiele krajów jako podstawę działalności w zakresie obrotu ziemią rolną postawiło przed swoimi instytucjami nadzorującymi zadanie przeciwdziałania nadmiernej koncentracji gruntów). W Polsce współczynnik ten wynosi dla porównania 0,63 (rysunek 10).

Rysunek 10. Współczynniki koncentracji ziemi rolnej we Francji i wybranych krajach UE (liczone jako współczynnik koncentracji Lorenza) - 2012 r.

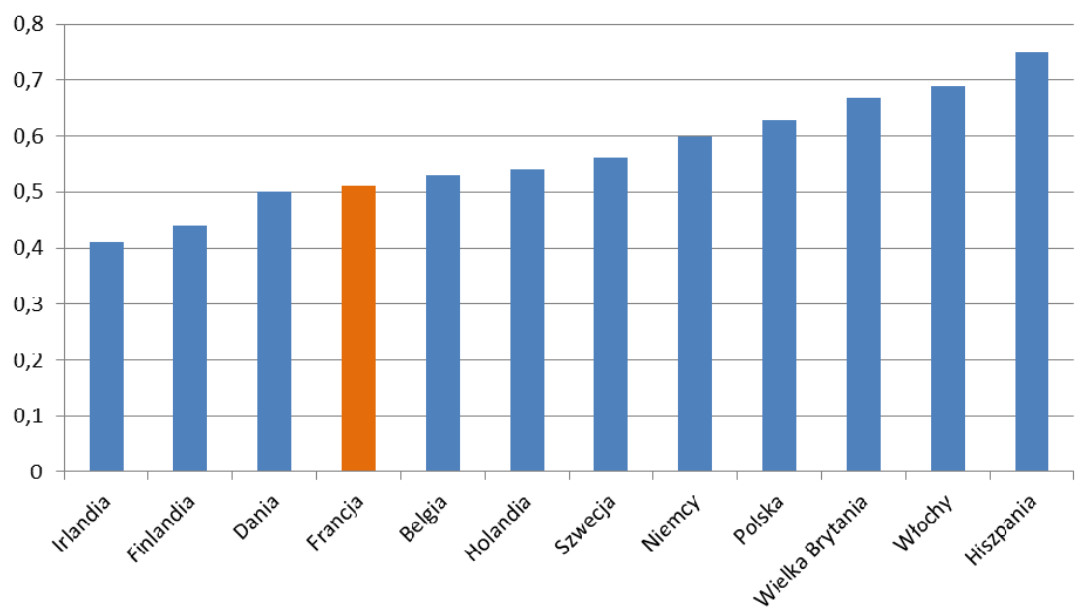

Źródło: obliczenia własne na podstawie danych Eurostat. 


\section{Podsumowanie}

Analizując kształtowanie się cen $1 \mathrm{~m}^{2}$ lokalu mieszkalnego na rynku pierwotnym oraz 1 ha gruntu rolnego, należy zauważyć, że oba te rynki charakteryzują się własną dynamiką. W ostatnim okresie cena $1 \mathrm{~m}^{2}$ nieruchomości mieszkaniowej wykazuje tendencję malejącą, natomiast ziemia rolna z roku na rok zyskuje na wartości. Wykorzystując narzędzia analizy technicznej w analizie rynku nieruchomości, w przypadku rynku mieszkań należy poszukiwać linii wsparcia (jak nisko ceny mogą być obniżone), natomiast na rynku nieruchomości rolnych - linii oporu (jak wysoko ceny mogą rosnąć).

Przeprowadzone badania wskazują, że przy niezmienionych standardach wykończenia mieszkań nowo oddawanych do użytku ich cena nie powinna być niższa niż 4180 zł $/ \mathrm{m}^{2}$ w 2015 r. i 4300 zł $/ \mathrm{m}^{2}$ w 2016 r. Spadek cen mieszkań poniżej tych wartości jest możliwy, ale tylko po obniżeniu kosztów budowy.

We wstępie postawiono tezę, że przy obecnych uwarunkowaniach granice wzrostu cen nieruchomości (linię oporu) wyznaczać będzie cena nieruchomości rolnych w krajach zachodnich. Z prezentowanych analiz wynika, że jest ona jeszcze znacząco niższa niż w wielu krajach UE. Również większość czynników, od których zależy cenność gruntów rolnych, ma cechy dynamizujące jej wzrost. Nie jest to dobra prognoza dla rolników planujących powiększenie swoich gospodarstw i nie jest to sytuacja dobra dla Polski. Przykład rozwiązania francuskiego, jakim jest SAFER, pokazuje, że państwo może pozytywnie kreować politykę agrarną i cenową gruntów rolnych.

\section{Literatura}

Beksiak J., Ciżkowicz M., Karnowski J. (2013), Falowanie aktywności gospodarczej. Przypadek Polski, C.H. Beck, Warszawa.

Gdakowicz A. (2014), Linia oporu a ceny mieszkań na rynku pierwotnym w wybranych miastach Polski, Zeszyty naukowe Uniwersytetu Szczecińskiego, nr 811, „Studia i Prace Wydziału Nauk Ekonomicznych i Zarządzania”, nr 36: Metody ilościowe w ekonomii, t. 2.

Hendry D.F., Ericsson K.A. (2003), Understanding Economic Forecasts, The MIT Press, Cambridge. 
Hozer J. (2000), Analiza, diagnoza i prognoza rozwoju społeczno-ekonomicznego Polski po sierpniu 1980 roku, IADiPG, Szczecin.

Hozer J. (2014), Czas a wewnętrzne prawo ruchu, „Wiadomości Statystyczne”, nr 6.

Hozer J., Kuźmiński W. (2013), Analiza i diagnoza rozwoju rolnictwa w województwie zachodniopomorskim, IADiPG, Szczecin.

Hozer J., Zawadzki J. (1990), Zmienna czasowa i jej rola $w$ badaniach ekonometrycznych, PWN, Warszawa.

Kucharska-Stasiak E. (1997), Nieruchomość a rynek, Wydawnictwo Naukowe PWN, Warszawa.

Nowakowski J., Borowski K. (2006), Zastosowanie teorii Carolana i Fischera na rynku kapitałowym, Difin, Warszawa.

Rynek zbóż. Stan i perspektywy (2013), Instytut Ekonomiki Rolnictwa i Gospodarki Żywnościowej - Państwowy Instytut Badawczy, Warszawa, nr 45.

Tarczyński W. (1997), Rynki kapitałowe. Metody ilościowe, t. I, Placet, Warszawa.

Ustawa z dnia 19 października 1991 r. o gospodarowaniu nieruchomościami rolnymi Skarbu Państwa, DzU z 1991 r., nr 107, poz. 464.

Zieliński Z. (1979), Metody analizy dynamiki i rytmiczności zjawisk gospodarczych, PWN, Warszawa.

\title{
THE LINES OF RESISTANCE AND SUPPORT ON RESIDENTIAL AND AGRICULTURAL REAL ESTATE MARKET
}

\begin{abstract}
The residential property market and the agricultural property market only at first glance seem to be parts of a common category of real estate markets. The processes occurring on these markets can be completely different within the same time period. Increases in the prices of agricultural land may be accompanied by a declining housing prices and vice versa. Hence, the two markets should be analysed separately, although one should be aware of their interfusion. The processes occurring on one market may have certain consequences for the other, not only in the present, but also in the future. It is therefore necessary to find specific turning points in terms of the dynamics of phenomena existing in real estate markets. In the
\end{abstract}


article an attempt to use tools of technical analysis of commodities' markets to analyse real estate markets was made, with particular emphasis put on the resistance and support lines.

Translated by Anna Gdakowicz

Keywords: line of resistance, line of support, residential real estate market, agricultural property market

JEL Codes: C19, E31, R31, R32 
